occipital bone which he had found in the middle gravels of the 100-ft. terrace of the Thames at Swanscombe, Kent. The bone was associated with Acheulean flint implements, and is mineralised in the same way as the bones of the Pleistocene mammals occurring with it. The fossil was submitted to the Geological Survey, and Mr. Henry Dewey confirmed the determination of its geological age. Mr. Marston now writes that he has made an endocranial cast of the specimen and has consulted Sir Grafton Elliot-Smith, who expresses the opinion that "the exceptional size and form of the visual territories upon the two hemispheres of the endocranial cast, even if they suggest left-handedness, are definitely Simian and point to a much more primitive stage than Eoanthropus". The bone differs considerably from the occipital of Eoanthropus, and further discoveries to reveal the characters of the skull to which it belongs will be eagerly awaited.

\section{Ancient Ruins in East Africa}

AN archæological reconnaissance with the view of further investigation has been made recently by $\mathrm{Dr}$. L. S. B. Leakey on two sites in East Africa. Of these, one, the ruins of Gedi, an ancient city of considerable extent, sixty-five miles north of Mombasa, is already scheduled under the Ancient Monuments Preservation Ordinance; the other is the large assemblage of stone-built dwelling-places and tombs at Engaruka in the Great Rift Valley in Tanganyika, to which attention was directed as a new discovery in June last of Mr. T. E. Wetherell. The ruins at Gedi, though situated at no more than fifty yards from the Mombasa-Malindi road at their nearest point, are so obscured by a tangle of tropical vegetation as almost to escape notice. Trees of considerable size growing on or in the ruined structures afford some gauge of the antiquity of the ruins. According to Dr. Leakey's report (The Times, October 11) future investigation will reap a rich harvest. Town walls, buildings and tombs alike afford evidence of at least two, and possibly three, distinct periods of construction. The materials used consist of dressed blocks of coral, built up with a hard mortar and plastered to a smooth surface. In places, where the dressing is unplastered, as on the arches over doors and windows, it is extremely fine. It is Dr. Leakey's opinion that the ruins may be those of an Arab or Persian settlement of considerable antiquity, the first settlement possibly dating so far back as the beginning of the Christian era.

Dr. LEakey's investigations at Engaruka confirm previous reports of the extent of the site, though the limits at present are unknown. He estimates that the buildings in the North and South Ruins on the slope number five to seven thousand; and there are further structures in addition to the tomb mounds below in what he terms the Valley Ruins. The ruins are not entirely a new discovery, as recently reported. They had been visited by Dr. Hans Reck on his way to Oldoway in 1913, when he excavated one or two mounds ; and more recently a little digging has been done by British administrative officials. Dr. Leakey carried out one or two exploratory excavations of mounds and buildings, but failed to obtain any material, either skeletal or cultural, which throws light on the dating of the site. It is evidently not of high antiquity. The buildings are entirely of dry stone-walling, without mortar, and show no real skill in stone building. Inquiry among the Masai elicited the tradition that the ruins had been abandoned about one hundred years ago when the Masai drove out the ancestors of the present-day Warmbulu. A further tradition of a Portuguese leader or king at Engaruka may, it is thought, afford an explanation of how a people who do not now build in stone, nor live in towns or even villages, came to erect these stone structures in such numbers.

\section{Linguistic Research in Kashmir}

IT is reported that Colonel D. L. R. Lorimer, whose studies in Indo-Iranian linguistics are well known, accompanied by Mrs. Lorimer, has recently returned to Srinagar from an expedition of linguistic research among the mountain tribes of Hunza and the area to the north, upon which he has been engaged during the last fifteen months. The chief object of the expedition was to extend and complete Colonel Lorimer's studies of Burushaski, the language of the Burusho of Hunza ; but he has also devoted attention to Wakki, a language of the Iranian group spoken in Wakkan and also by Wakkan settlers in northern Hunza. Colonel Lorimer, it is stated in a dispatch from Srinagar in The Times of October 9, has succeeded in obtaining a record of a language, Boma, hitherto unknown, spoken by a tribe of musicians and metal workers who have been settled in Hunza for many generations. According to their own tradition, they are a people of Badakhshari origin, who at some period were transferred to the rule of the Mir of Hunza for services he had rendered the ruler of Badakhshan. They have remained an exclusive group and still do not intermarry with the Burusho, although they, like the other peoples of Hunza, are Moslems. Hence while they speak Burushaski fluently, they have retained their cultural and linguistic individuality intact. Their language, which is said not to resemble the Badakhshani of their traditional place of origin, appears to be more closely related to the Sanskritic than to the Iranian members of the Indo-Iranian linguistic group. If this be confirmed by further study, it would agree with the character of other languages of the so-called Dards of Hunza. Colonel Lorimer is now about to return to England for the purpose of studying the large amount of ethnographical and linguistic material he has collected among the less well-known mountain peoples of the area.

\section{Marine Research at Millport}

THE report for $1933-34$ of the Scottish Marine Biological Association, Millport, shows that much work has been done during the year. The director, Mr. R. Elmhirst, has studied specially the conditions under which shore algæ live, and subdivides the 